\title{
Radiopacity assessment of composite resins through digital systems and InSight intraoral film
}

\author{
Avaliação da radiopacidade de resinas compostas por meio de sistemas \\ digitais e filme radiográfico InSight
}

\author{
Mateus Ericson Flores* \\ Francisco Haiter Neto** \\ Frab Norberto Boscolo ${ }^{* * *}$ \\ Gisele Rovani**** \\ Melissa Feres Damian ${ }^{* * * *}$
}

\section{Abstract}

Objective: this study aimed to assess the radiopacity of eight composite resins recommended for class II restorations. Materials and method: hence, $2 \mathrm{~mm}$ thick and $4 \mathrm{~mm}$ in diameter test specimens were made and compared to enamel, dentin, and aluminum using four digital systems: two semi-direct by storage phosphor image plates (SPIP) - Digora ${ }^{T M}$, and DenOptix ${ }^{T M}$, two charged couple devices (CCD) - Sens-A-Ray ${ }^{T M}$ and Computerized Dental Radiograph $\left(C D R^{T M}\right)$, and radiographic film Kodak Insight IS-2 $1^{\text {TM }}$. The radiographs were scanned to obtain the indirect digital image, and along with direct and semi-direct digital images the radiographic densities were assessed in specific software. The pixel values from the aluminum step wedge were submitted to a linear regression from where the equivalent in millimeters for enamel, dentin, and resins were determined. Results: density means of resins were equal or superior to the means obtained for enamel in all digital systems and the conventional film. SureFil ${ }^{\mathrm{TM}}$ resin presented greater numerical radiopacity in all digital systems and the radiographic film. ALERT ${ }^{\text {TM }}$ resin showed the smallest radiopacity among the studied resins in all digital systems and radiographic film. ALERT ${ }^{T M}$ and Definite ${ }^{T M}$ were statistically equivalent to enamel in the Sens-A-Ray ${ }^{T M}$ system and in radiographic film. The remaining resins
(Charisma $^{T M}$, FillMagic ${ }^{T M}, P 60^{T M}$, Prodigy $^{T M}$, SureFil ${ }^{T M}$, and $\left.Z 250^{T M}\right)$ presented higher radiopacities in comparison to enamel. Only ALERT $T^{T M}$ presented radiopacity similar to enamel in other digital systems $\left(C D R^{T M}\right.$, DenOptix ${ }^{T M}$, and Digora $\left.^{T_{M}}\right)$. In these digital systems, Charisma ${ }^{{ }^{M}}$, Definite ${ }^{{ }^{M M}}$,

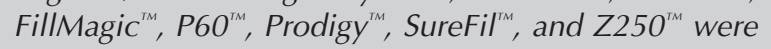
more radiopaque than enamel. Conclusion: all resins showed equal or higher radiopacities of enamel in all assessment systems. There was a statistical correlation between systems $C D R^{T M}$ and Sens-A-Ray ${ }^{T M}$, and between Digora $^{\text {TM }}$ and DenOptix ${ }^{T M}$; Sens-A-Ray ${ }^{T M}$ also showed correlation with radiographic film. The percentage of density means equivalent to aluminum millimeters for enamel and dentin were $119.6 \%$ and $101.6 \%$, respectively.

Keywords: Composite resins. X-rays. Digital dental radiography. 


\section{Introduction}

The development of composite resins gives great aesthetic possibilities for dental restorations. However, for ideal clinical analysis of interproximal contour, contact point adequacy, overhangs, cavity wall adaptation, marginal gaps, voids, and recurrent decay these materials must provide sufficient radiopacity to be visible on radiographic examinations, in accordance with ADA standards ${ }^{1,2}$ and ISO $4049^{3}$. These standards require that the radiopacity of composite resins to be used in class 1 and class 2 restorations should be greater than an equivalent thickness of aluminum (mm) or equivalent aluminum percentage (\% Al). Prior studies found this aluminum standard to be comparable in radiopacity to an equivalent thickness of dentin ${ }^{4-7}$.

The introduction of digital radiographic systems for dentistry in the 1980s brought benefits such as reduced patient dosage, increased film speed, ability to enhance images as desired, and ability to send them via internet ${ }^{8,9}$. Research on digital images was primarily powered with CCD and SPIP resolution, noise formation, density scale, compression of files, and potential effects on clinical diagnosis ${ }^{10-12}$. Up to now, few studies have investigated digital systems for the evaluation of composite resin radiopacities ${ }^{13,14}$. The aim of this study was to certify the existence of uniformity of results among different types of digital systems and conventional dental x-ray film, and to determine their compliance with ISO 4049.

\section{Materials and method}

Five samples of each type of posterior composite resins were light cured through a split plexiglass mold $-4 \mathrm{~mm}$ in diameter and $2 \mathrm{~mm}$ thick (Table 1). Each specimen was light activated for 40 seconds with a XL $1500^{\mathrm{TM}}$ halogen curing light (3M ESPE Dental Products, St. Paul, MN, USA) at $>650 \mathrm{~mW} / \mathrm{cm}^{2}$. Enamel and dentin specimens were $2.0 \mathrm{~mm}$ thick, prepared from recently extracted human third molars. Samples' thicknesses were measured with a digital micrometer with two decimal places.

Table 1 - Composite resins and manufacturers. Piracicaba-SP (Brazil), 2001

\begin{tabular}{|c|c|}
\hline Resins & Manufacturer \\
\hline ALERT ${ }^{\top M}$ & Pentron $^{\mathrm{TM}}$ Technologies, LLC - Wallingford, CT, USA \\
\hline Charisma $^{\mathrm{TM}}$ & Heraeus Kulzer GmbH \& Co. KG - Hanau, Germany \\
\hline Definite $^{\mathrm{TM}}$ & Degussa Hülls - Frankfurt, Germany \\
\hline FillMagic $^{\top M}$ & Vigodent - Rio de Janeiro, Brazil \\
\hline$P 60^{\mathrm{TM}}$ & 3M ESPE Dental Products - St. Paul, Minnesota, USA. \\
\hline Prodigy $^{\mathrm{TM}}$ & Kerr Corporation - Orange, CA, USA \\
\hline SureFil ${ }^{\mathrm{M}}$ & Dentsply International - York, PA, USA \\
\hline $\mathrm{Z} 250^{\mathrm{TM}}$ & 3M ESPE Dental Products - St. Paul, Minnesota, USA. \\
\hline
\end{tabular}

Radiographs were taken of a specimen for each of the 8 materials, enamel, dentin, and an aluminum step wedge, using 4 digital systems (Figura 1). Two semi-direct storage phosphor image plates Digora $^{\text {TM }}$ (Soredex - Nilsiänkatu 10-14, PO Box 250, 00031 Helsinki, Finland) and DenOptix ${ }^{\mathrm{TM}}$ (Gendex Division - 901 W. Oakton St. Des Plaines, IL 60018-
1884, USA), and two CCD - Sens-A-Ray ${ }^{\mathrm{TM}}$ (Dent-X Corporation USA - 250 Clearbrook Road Elmsford New York 10523, USA) and CDR ${ }^{\mathrm{TM}}$ (Schick Technologies, Inc. 30-00 47th Avenue - Long Island City, NY 11101, USA) were used. The features of the digital systems are contained in Table 2.

Table 2 - Features of digital system. Piracicaba-SP (Brazil), 2001

\begin{tabular}{|c|c|c|c|c|}
\hline & Manufacturer & Sensor & Active size (mm) & Pixel size $(\mu \mathrm{m})$ \\
\hline Digora $^{\mathrm{TM}}$ & Soredex (Helsinki, Finland) & SPIP* & $30 \times 40$ & $70 \times 70$ \\
\hline DenOptix $^{\text {TM }}$ & Gendex (Des Plaines, IL, USA) & SPIP* & $31 \times 41$ & $85 \times 85$ \\
\hline Sens-A-Ray ${ }^{\mathrm{TM}}$ & Dent-X Corporation (New York, NY, USA) & $\mathrm{CCD}^{*}$ & $23,5 \times 27,6$ & $44 \times 44$ \\
\hline $\mathrm{CDR}^{\mathrm{TM}}$ & Schick Technologies (Long Island, NY, USA & $\mathrm{CCD}^{*}$ & $25,2 \times 36,5$ & $48 \times 48$ \\
\hline
\end{tabular}

*SPIP: storage phosphor image plate system. CCD: charged couple device 
Eastman Kodak Insight IS-21 ${ }^{\mathrm{TM}}$ (Eastman Kodak Co., 343 State Street - Rochester, NY 14650, USA) radiographs of the specimens were also taken. Films and CCD digital systems were exposed for $0.05 \mathrm{~s}$ and $0.40 \mathrm{~s}$ to SPIP digital systems. Target film distance of $70 \mathrm{kV}, 10 \mathrm{~mA}$, and $400 \mathrm{~mm}$ standardized by a wooden support with a GE $1000^{\text {TM }}$ (General Electric Company, 3000 N, Grandview Blvd, MD W-407 Waukesha, WI 53188, USA) x-ray machine was used. Films were processed in a Gendex GXP ${ }^{\mathrm{TM}}$ film processor (Gendex Division - $901 \mathrm{~W}$. Oakton St. Des Plaines, IL 60018-1884, USA) with Kodak $^{\mathrm{TM}}$ chemicals.

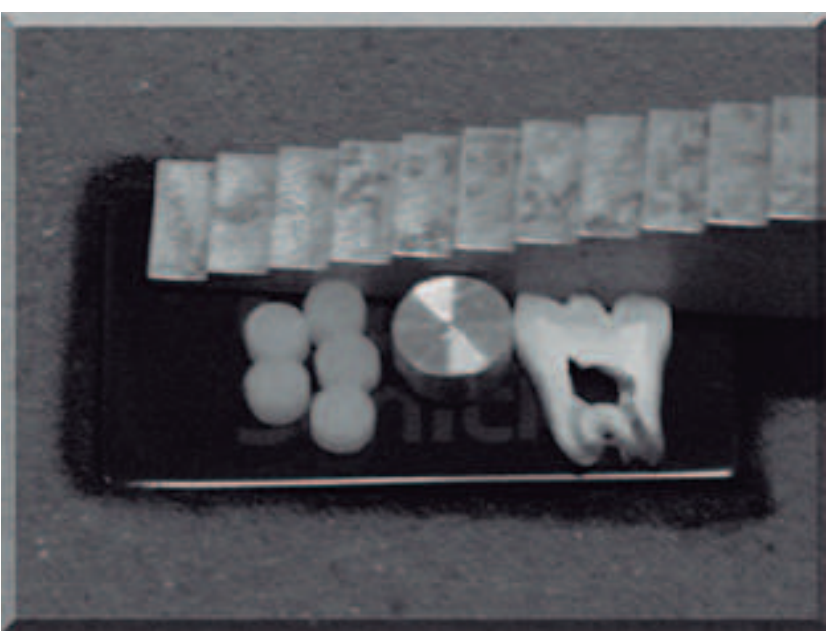

Figure 1 - Aluminum step wedge, resins, lead and tooth on sensor $C C D$ CDR- Schick Technologies. Piracicaba-SP (Brazil), 2001

Digital images were recorded and electronically stored. All films were scanned into a computer with an HP $6100 \mathrm{C} / \mathrm{T}^{\mathrm{TM}}$ scanner (Hewlett-Packard, 3000 Hanover Street Palo Alto, CA 94304-1185).

Relative radiographic densities of each module - aluminum step wedge, enamel, dentin, lead, and resins were separately depicted using a histogram in each software (Figura 2). Five replications of readings were performed in each module.

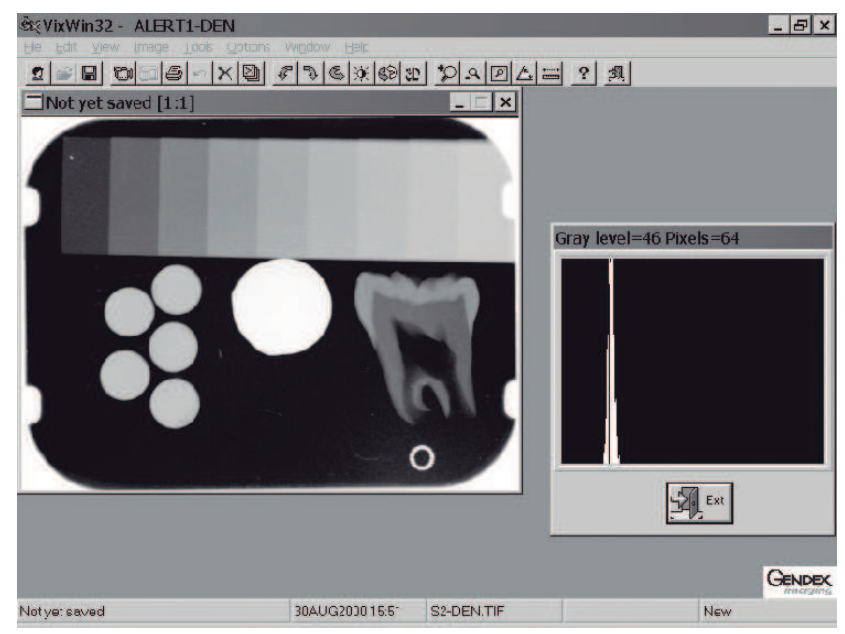

Figure 2 - Image of the histogram analyses in SPIP - DenOptix. Piracicaba-SP (Brazil), 2001
The mean density value in pixels for the seven first steps of the density scale, as well as the ones for each resin seen in each digital system and the scanned InSight films were statistically analyzed using linear regression, where the mean values in pixels were converted into an aluminum equivalent (mm). The results were analyzed using variance analysis and the Tukey's test at 5\%.

\section{Results}

Table 3 shows the radiopacity data for the eight composite resins, enamel, and dentin specimens examined. The mean density values of all resins were equal or superior to the mean values obtained for the enamel specimens in all digital systems and the scanned radiographic film. SureFil ${ }^{\mathrm{TM}}$ presented greater numerical radiopacity in all digital systems and the scanned radiographic film. ALERT ${ }^{\mathrm{TM}}$ showed the lowest radiopacity among the studied resins in all digital systems and the scanned radiographic film. ALERT ${ }^{\mathrm{TM}}$ and Definite ${ }^{\mathrm{TM}}$ were statistically equivalent to enamel in the Sens-A-Ray ${ }^{\mathrm{TM}}$ system and the scanned radiographic film. The remaining resins ${\left(\text { Charisma }^{\mathrm{TM}}\right.}$, FillMagic ${ }^{\mathrm{TM}}, \mathrm{P}^{\mathrm{TM}}{ }^{\mathrm{TM}}$, Prodigy $^{\mathrm{TM}}$, SureFil ${ }^{\mathrm{TM}}$, and $\mathrm{Z}^{250^{\mathrm{TM}}}$ ) had higher radiopacities in comparison to enamel. Only ALERT ${ }^{\mathrm{TM}}$ presented radiopacity similar to enamel in other digital systems $\left(\mathrm{CDR}^{\mathrm{TM}}\right.$, Denoptix $^{\mathrm{TM}}$ and Digora $\left.{ }^{\mathrm{TM}}\right)$. In these digital systems, Charisma ${ }^{\mathrm{TM}}$, Definite ${ }^{\mathrm{TM}}$, Fill-

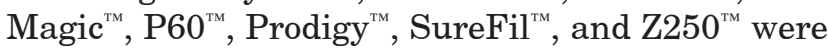
more radiopaque than enamel.

Table 3 - Mean values equivalent in aluminum $(\mathrm{mm})$ of resins, enamel, and dentin for each system, separately. Piracicaba-SP (Brazil), 2001

\begin{tabular}{|c|c|c|c|c|c|}
\hline & Sens-A-Ray & CDR & DenOptix & Digora & InSight Film \\
\hline LERT & $3.752 \mathrm{c}$ & $3.760 \mathrm{f}$ & $4.246 \mathrm{e}$ & $4.324 \mathrm{e}$ & $3.784 \mathrm{~d}$ \\
\hline Charisma $^{\mathrm{TM}}$ & $5.246 \mathrm{ab}$ & $5.656 \mathrm{bc}$ & $6.196 \mathrm{abc}$ & $5.970 \mathrm{~b}$ & $4.876 \mathrm{bc}$ \\
\hline Definite ${ }^{T M}$ & $4.204 \mathrm{C}$ & $4.574 \mathrm{e}$ & $5.272 \mathrm{~d}$ & $4.868 \mathrm{~d}$ & $3.914 \mathrm{~d}$ \\
\hline FillMagic $^{\mathrm{TM}}$ & $4.968 \mathrm{~b}$ & $5.218 \mathrm{~cd}$ & $6.296 \mathrm{ab}$ & $5.774 \mathrm{bc}$ & $4.634 \mathrm{C}$ \\
\hline $\mathrm{P} 60^{\mathrm{TM}}$ & $5.730 \mathrm{a}$ & $5.904 \mathrm{ab}$ & $5.584 \mathrm{~d}$ & $5.496 \mathrm{bc}$ & $5.638 \mathrm{a}$ \\
\hline Prodigy $^{T M}$ & $4.886 \mathrm{~b}$ & 5.104 de & $5.794 \mathrm{bcd}$ & $5.590 \mathrm{bc}$ & $4.868 \mathrm{bc}$ \\
\hline SureFil ${ }^{T M}$ & $5.704 \mathrm{a}$ & $6.230 \mathrm{a}$ & $6.736 \mathrm{a}$ & $6.526 \mathrm{a}$ & $5.322 \mathrm{ab}$ \\
\hline $\mathrm{Z} 250^{\mathrm{TM}}$ & $5.562 \mathrm{a}$ & 5.704abc & $5.722 \mathrm{~cd}$ & $5.320 \mathrm{~cd}$ & $5.358 \mathrm{ab}$ \\
\hline Enamel & $4.140 \mathrm{c}$ & $3.770 \mathrm{f}$ & $4.282 \mathrm{e}$ & $3.896 \mathrm{e}$ & $3.876 \mathrm{~d}$ \\
\hline Dentin & $2.112 \mathrm{~d}$ & $1.764 \mathrm{~g}$ & $2.256 f$ & $1.978 \mathrm{f}$ & $2.052 \mathrm{e}$ \\
\hline
\end{tabular}

Averages followed by distinct letters differ among themselves to the significance level of $5 \%(p<0.05)$, inside the same column. 
The radiopacity values for enamel and dentin reported in this study were similar for all digital systems and the radiographic film (Table 4).

Table 4 - Enamel and dentin equivalent in aluminum and its conversion for aluminum percentage in all digital systems and the scanned radiographic film. Piracicaba-SP (Brazil), 2001

\begin{tabular}{l|c|c|c|c}
\cline { 2 - 5 } & \multicolumn{2}{c|}{ Enamel } & \multicolumn{2}{c}{ Dentin } \\
\cline { 2 - 5 } & Al equivalent & $\% \mathrm{Al}$ & $\mathrm{Al}$ equivalent & $\% \mathrm{Al}$ \\
\hline S-A-R $^{\mathrm{TM}}$ & 4.140 & 207 & 2.112 & 105 \\
CDR $^{\mathrm{TM}}$ & 3.770 & 188 & 1.764 & 88 \\
DenOptix $^{\mathrm{TM}}$ & 4.282 & 214 & 2.256 & 113 \\
Digora $^{\mathrm{TM}}$ & 3.896 & 195 & 1.978 & 99 \\
InSight Film $^{\mathrm{TM}}$ & 3.876 & 194 & 2.052 & 103 \\
\hline
\end{tabular}

\section{Discussion}

All resins evaluated in this research presented radiopacity equal to or higher than that of the enamel specimens tested, and complied with ISO 4049. The suggestion of increased radiopacity for composite resins was offered by other studies ${ }^{4,5,15-18}$. They believed that it could improve the diagnosis of caries, marginal gap, and other defects. However, too high radiopacity may have the opposite effect due to the high radiopacity difference between the composite resin and the adhesive $e^{4,7,19}$

SureFil $^{\mathrm{Th}}$ showed higher numerical radiopacity in all digital systems and the scanned radiographic InSight film. These results were similar to those reported by Watts ${ }^{20}$, who suggested that the increased percentage of filling would be responsible for higher radiopacity.

Some researchers ${ }^{4,16,21-26}$ have evaluated restorative materials. They found that some resins are not in accordance with ISO 4049. These authors found dental materials with equal or higher radiopacity than enamel; materials with equal or higher radiopacity than dentin; and materials with lower radiopacity than dentin.

The means suffered variations regarding these issues among the systems, but all of them were similar to those obtained by Stanford et al. ${ }^{7}$, with $79 \%$ for dentin and $222 \%$ for enamel; Williams and Billington $^{27}$, with $100 \%$ for dentin and $210 \%$ for enamel; Williams and Billington ${ }^{28}$ with $100 \%$ for dentin and $220 \%$ for enamel; El-Mowafy et al. ${ }^{5}$, with $116 \%$ for dentin and $184 \%$ for enamel; and Bouschlicher et al. ${ }^{25}$ with $100 \%$ for dentin and $165 \%$ for enamel. These small variations may be due to the time of tooth storage, and the consequent loss of radiopacity by demineralization ${ }^{28}$.

\section{Conclusions}

After detailed analysis and discussion of the results we can conclude that all composite resin evaluated by four digital systems and a radiographic InSight film are in accordance with ISO 4049. Also, the radiopacities of enamel and dentin in aluminum equivalent converted to percentage suffer variations according to the way of attainment, however they are within the values found in literature.

\section{Resumo}

Objetivo: este estudo teve como objetivo avaliar a radiopacidade de oito tipos de resinas compostas indicadas para restaurações de classe II. Materiais e método: para tanto foram confeccionados corpos de prova de $2 \mathrm{~mm}$ de espessura e $4 \mathrm{~mm}$ de largura, os quais foram comparados com esmalte, dentina e alumínio, utilizando-se quatro sistemas digitais, sendo dois semidiretos por placas de fósforo fotoestimuladas - Digora ${ }^{\circledR}$ e DenOptix ${ }^{\circledR}$, dois CCD - Sens-A-Ray ${ }^{\circledR}$ e $C D R^{\circledR}$, e também o filme radiográfico Kodak Insight IS-21 ${ }^{\circledR}$. As radiografias foram escaneadas, obtendo-se imagem digital indireta, e, juntamente com as imagens digitais diretas e semidiretas, suas densidades radiográficas foram avaliadas em software específico. Os valores de pixel da escala de alumínio foram submetidos a uma regressão linear, de onde se pôde obter o equivalente em milímetros para o esmalte, dentina e resinas. Resultados: para todos os sistemas digitais e para o filme convencional, as médias das densidades das resinas foram iguais ou superiores às médias obtidas pelo esmalte. Para todos os sistemas digitais e para o filme radiográfico, a resina Surefil ${ }^{\circledR}$ apresentou maior radiopacidade numérica. A resina $A L E R T^{\circledast}$ apresentou a menor radiopacidade entre as resinas estudadas em todos os sistemas digitais e filme radiográfico. ALERT ${ }^{\circledast}$ e Difinite ${ }^{\circledR}$ foram estatisticamente equivalentes ao esmalte no sistema digital Sens-A-Ray ${ }^{\circledR}$ e no filme radiográfico. As demais resinas (Charisma ${ }^{\circledR}$, FillMagic $^{\circledR}$, P6O $^{\circledR}$, Prodigy $^{\circledR}$, Surefi $^{\circledR}$ e $Z 250^{\circledR}$ ) tiveram maior radiopacidade em comparação ao esmalte. Somente $A L E R T^{\circledR}$ teve radiopacidade similar à do esmalte em outros sistemas digitais $\left(C D R^{\circledR}\right.$, Denoptix ${ }^{\circledR}$ e Digo$\mathrm{ra}^{\circledR}$ ). Nesses sistemas digitais, Charisma ${ }^{\circledR}$, FillMagic ${ }^{\circledR}$, $\mathrm{P} 0^{\circledR}$, Prodigy $^{\circledR}$, Surefi ${ }^{\circledR}$ e $\mathrm{Z} 250^{\circledR}$ foram mais radiopacos do que o esmalte. Conclusão: todas as resinas, em todos os sistemas de avaliação, mostraram radiopacidade igual ou superior ao esmalte. Houve correlação estatística entre os sistemas $C D R^{\circledR}$ e Sens-A-Ray ${ }^{\circledR}$ e entre Digora $^{\circledR}$ e DenOptix ${ }^{\circledR}$, tendo o Sens-A-Ray ${ }^{\circledR}$ apresentado correlação também com o filme radiográfico. As médias de densidade equivalente em $\mathrm{mm}$ de alumínio em porcentagem para esmalte e dentina foram de $119,6 \%$ e $101,6 \%$, respectivamente.

Palavras-chave: Resinas compostas. Raios X. Radiografia dental digital. 


\section{References}

1. American Dental Association Council on Dental Materials, Instruments and Equipment. The desirability of using radiopaque plastic in dentistry: a status report. J Am Dent Assoc 1981; 102:347-9.

2. American Dental Association Council on Dental Materials, Instruments and Equipment. Status report on posterior composites. J Am Dent Assoc 1983; 107:74-6.

3. Bouschlicher MR, Cobb DS, Boyer DB. Radiopacity of compomers, flowable and conventional resin composites for posterior restorations. Oper Dent 1999; 24:20-5.

4. Curtis-Jr PM, Von-Fraunhofer JA, Farman AG. The radiographic density of composite restorative resins. Oral Surg Oral Med Oral Pathol Oral Radiol Endod 1990; 70:226-30.

5. El-Mowafy OM, Brown JW, McComb J. Radiopacity of direct ceramic inlay restoratives. J Dent 1991; 19:366-8.

6. Abou-Tabl ZM, Tidy DC, Combe EC. Radiopacity of composite restorative. Br Dent J 1979; 147:187-9.

7. Stanford CM, Fan PL, Schoenfeld CM, Knoeppel R, Stanford JW. Radiopacity of light-cured posterior composite resins. J Am Dent Assoc 1987; 115:722-4.

8. Van der Stelt P. Principles of digital imaging. Dent Clin North Am 2000; 44:237-48.

9. Wenzel A. Digital radiography and caries diagnosis. Dentomaxillofac Radiol 1998; 27:3-11.

10. Janhom A, Van der Stelt PF, Van Ginkel FC, Geraets WGM. Effect on the compressibility and diagnostic accuracy for caries detection of digital bitewing radiographs. Dentomaxillofac Radiol 1999; 28:6-12.

11. M Øystad A, Svanaes DB, Risnes S, Larhein TA, Gröndahl HG. Detection of approximal caries with a storage phosphor system. A comparison of enhanced digital images with dental X-ray film. Dentomaxillofac Radiol 1996; 25:202-6.

12. Welander U, McDavid WD, Sanderink GCH, Tronje G, Mörner AC, Dove SB. Resolution as defined by line spread and modulation transfer functions for four digital intraoral radiographic systems. Oral Surg Oral Med Oral Pathol Oral Radiol Endod 1994; 78:109-15.

13. Farman TT, Farman AG, Scarfe WC, Goldsmith LJ. Optical densities of dental resin composites: a comparison of CCD, storage phosphor, and Ektaspeed Plus radiographic film. Gen Dent 1996; 44:532-7.

14. Gürdal P, Akdeniz BG. Comparison of two methods for radiometric evaluation of resins-based restorative materials. Dentomaxillofac Radiol 1998; 27:236-9.

15. Cook WD. An investigation of radiopacity of composite restorative materials. Aust Dent J 1981; 26:105-12.

16. Omer OE, Wilson NHF, Watts DC. Radiopacity of posterior composites. J Dent 1986; 14:178-9.

17. Prevost AP, Forest D, Tanguay R, DeGrandmont P. Radiopacity of glass ionomer dental materials. Oral Surg Oral Med Oral Pathol Oral Radiol Endod 1990; 70:231-5.

18. Goshima T, Goshima Y. Radiographic detection of recurrent carious lesions associated with composite restorations. Oral Surg Oral Med Oral Pathol Oral Radiol Endod 1990; 70:236-9.
19. Akerboom HBM, Kreulen CM, Amerongen WE, Mol A. Radiopacity of posterior composite resins, composite resin luting cements, and glass ionomer lining cements. J Prosthet Dent 1993; 70:351-5.

20. Watts DC. Radiopacity vs. composition of some barium and strontium glass composites. J Dent 1987; 15:38-43.

21. Van Dijken JWV, Wing KR, Ruyter IE. An evaluation of the radiopacity of composite restorative materials used in class I and II cavities. Acta Odontol Scand 1989; 47:401-7.

22. Toyooka H, Taira M, Wakasa K, Yamaki M, Fujita M. Radiopacity of 12 visible-light-cured dental composite resins. J Oral Rehabil 1993; 20:623-5.

23. Sidhu SK, Shah PMM, Chong BS, Ford TRP. Radiopacity of resin-modified glass-ionomer restorative cements. Quintessence Int 1996; 27:639-43.

24. Marouf N, Sidhu SK. A study on the radiopacity of different shades of resin-modified glass-ionomer restorative materials. Oper Dent 1998; 23:10-4.

25. Bouschlicher MR, Cobb DS, Boyer DB. Radiopacity of compomers, flowable and conventional resin composites for posterior restorations. Oper Dent 1999; 24:20-5.

26. Hara AT, Serra MC, Rodrigues-Jr AL. Radiopacity of Glass-Ionomer/Composite Resin Hybrid Materials. Braz Dent J $2001 ; 12: 85-9$.

27. Williams JA, Billington RW. A new technique for measuring the radiopacity of natural tooth substance and restorative materials. J Oral Rehabil 1987; 14:267-9.

28. Williams JA, Billington RW. The radiopacity of glass ionomer dental materials. J Oral Rehabil 1990; 17:245-8.

\section{Corresponding author:}

Mateus Ericson Flores

Rua Cesario Rosseto, 414

99074-210 Passo Fundo, RS, Brazil

Phone/Fax: +55 (54) 33168403

E-mail: mef@upf.br

Recebido: 13/08/2012. Aceito: 08/10/2013. 